\title{
Rice bran extract (RBE) as supplement for cell culture
}

\author{
Satoko Moriyama ${ }^{1}$, Ken Fukumoto ${ }^{1}$, Masayuki Taniguchi ${ }^{2}$, Shigeru Moriyama ${ }^{3}$, Takuo Tsuno ${ }^{3}$, Satoshi Terada ${ }^{*}$ \\ From 23rd European Society for Animal Cell Technology (ESACT) Meeting: Better Cells for Better Health \\ Lille, France. 23-26 June 2013
}

\begin{abstract}
Introduction
In mammalian cell culture, fetal bovine serum (FBS) or proteins obtained from mammals are usually supplemented to culture media. Since the use of animal-derived components may cause an infection of virus and other pathogens, alternative supplement derived from nonmammals is eagerly required in cell culture for producing biotherapeutics and for cell therapy [1]. As an alternative supplement, we focused on rice bran extract (RBE), because several studies have been done and reported that RBE has some biological effects such as enhancement of NK cell activity and anti-inflammatory effect on mice [2] and antioxidant effect [3].

Rice bran, by-product of milling in the production of refined white rice, contains abundant nutrients and proteins. In this study, the effect of RBE was examined in the serum-free culture.
\end{abstract}

\section{Materials and methods}

\section{Effect of RBE on several cell lines}

RBE was extracted from rice bran in an alkaline solution, precipitated with acid, and subsequently freeze-dried. The proceeding was performed by Tsuno Food Infdustrial Co., Ltd. To test the effect, RBE was supplemented to the culture of hybridoma cells, Chinese hamster ovary cells (CHO-DP12), hepatoma HepG2 and HeLa. The cells were cultured in 24 well plate (Sumitomo Bakelite, Japan) with $1 \mathrm{ml}$ ASF104 medium (Ajinomoto, Japan) containing RBE or BSA (Wako, Japan) as positive control. The cell density was estimated using a hemacytometer. Viable cells were distinguished from dead cells by trypan blue dye exclusion method. The production of antibodies from hybridoma and CHO-DP12 cell was measured by ELISA method.

\section{Fractionation of RBE with UF membrane}

In order to identify the growth factor(s) in RBE, fractionations were performed using UF membranes. RBE was fractionated into the permeable and residual fraction with ultrafiltration membrane Amicon Ultra-15 (Merck Millipore, Germany) at $4,000 \mathrm{rpm}, 40 \mathrm{~min}$ and $4^{\circ} \mathrm{C}$. The fractions and whole RBE were added to the culture of hybridoma and CHO-DP12 cells.

\section{Results and discussion}

\section{Enhanced cell growth and productivity using RBE}

Figure 1 shows an enhanced proliferation by RBE. On growth and monoclonal antibody production of hybridoma cells, RBE had desired effect and the effect of RBE was superior to that of BSA. Similarly, to CHO-DP12 cells, addition of RBE exhibited increased cell growth and improved the productivity of humanized antibody. Growth of HepG2 and HeLa cells were also enhanced in the presence of RBE.

\section{Improvement of fractionated RBE by UF membrane}

Fractionated RBEs by UF membranes were also tested. The fraction of RBE more than $60 \mathrm{kDa}$ improved the proliferation of hybridoma cells and the level was superior to that of whole RBE, while the fraction less than $60 \mathrm{kDa}$ inhibited the proliferation. This results suggest that in $\mathrm{RBE}$, some lower molecular inhibitor(s) and higher molecular growth factor(s) would be contained.

\section{Conclusion}

We provide the first evidence that RBE is an attractive culture supplement to improve the proliferation and the production of mammalian cells. 


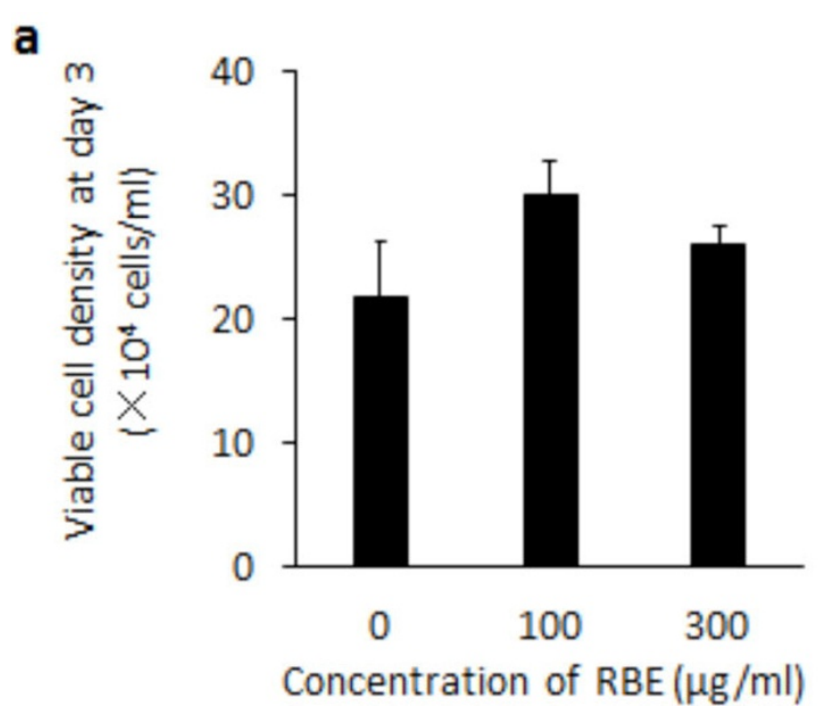

b

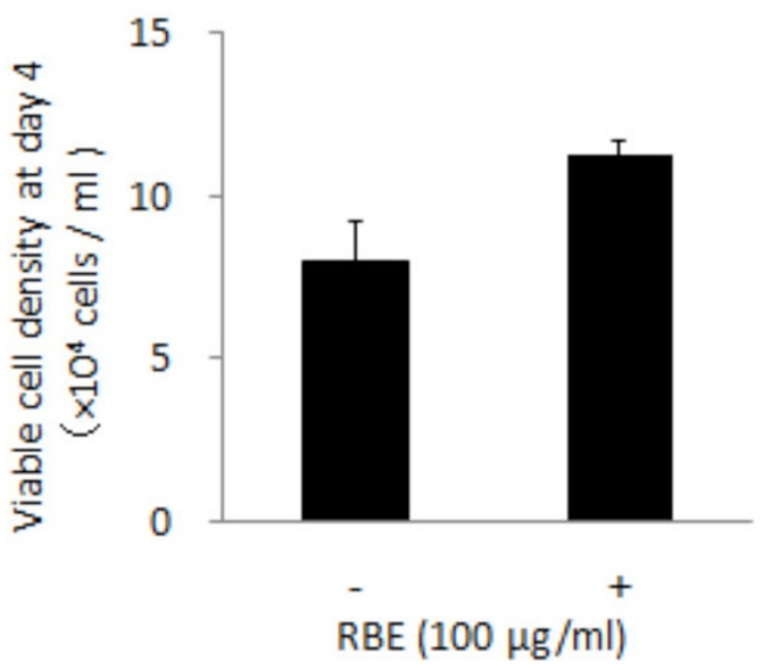

Figure 1 Cell growth in serum-free medium containing RBE. a mouse hybridoma cell, b HeLa.

\section{Authors' details}

${ }^{1}$ University of Fukui, Fukui, 910-8507, Japan. ${ }^{2}$ Niigata University, Niigata,

950-2102, Japan. ${ }^{3}$ Tsuno Food Industrial Co., Ltd, Katsuragi-cho, Wakayama,

649-7122, Japan.

Published: 4 December 2013

\section{References}

1. Leopold G, Thomas RK, Sonia N, Manfred R: Emerging trends in plasmafree manufacturing of recombinant protein therapeutics expressed in mammalian cells. Biotechnology journal 2009, 4:186-201.

2. Kim HY, Kim JH, Yang SB, Hong SG, Lee SA, Hwang SJ, Shin KS, Suh HJ,

Park $\mathrm{MH}$ : A polysaccharide extracted from rice bran fermented with

Lentinus edodes enhances natural killer cell activity and exhibits anticancer effects. Journal of medicinal food 2007, 10:25-31.

3. Elisa R, Consuelo SM, Miramontes E, Juan B, Ana GM, Olga C, Rosa C, Juan P: Nutraceutical composition, antioxidant activity and hypocholesterolemic effect of water-soluble enzymatic extract from rice bran. Food Research International 2009, 42:387-393.

Submit your next manuscript to BioMed Central and take full advantage of:

- Convenient online submission

- Thorough peer review

- No space constraints or color figure charges

- Immediate publication on acceptance

- Inclusion in PubMed, CAS, Scopus and Google Scholar

- Research which is freely available for redistribution 